\title{
Source-to-Sink Research: Economy of the Earth's Surface and its Strata
}

J.P. Walsh, P.L. Wiberg, R. Aalto, C.A. Nittrouer and S. A. Kuehl

\section{Introduction to Source-to-Sink Research}

The Earth is 4.6 billion years old, and over this time, its complexion has changed dramatically. Geoscientists use remnant information from ancient rocks and sedimentary deposits to unravel the history of the planet. What were the heights of ancient mountains? What events created the stratigraphy seen underneath hillsides or within buried river valleys? What kinds of storms impacted shorelines and oceans? Hutton (1785) and others convinced us that the present is the key to the past, arguing that sediments accumulating in the sea (i.e., the sedimentary sink) eventually become the land upon which we live (the source):

"As it is not in human record, but in natural history, that we are to look for the means of ascertaining what has already been, it is here proposed to examine the appearances of the earth, in order to be informed of operations which have been transacted in time past. It is thus that, from principles of natural philosophy, we may arrive at some knowledge of order and system in the economy of this globe, and may form a rational opinion with regard to the course of nature, or to events which are in time to happen."

Source-to-sink (S2S) research fundamentally pursues these original ideas. It is a geological approach rather than subdiscipline or process. To borrow words from Hutton, the objective of S2S research is to determine “...order and system in the economy of the globe”. Through the quantification of earth processes in a budgetary manner, it is an approach to connect areas of material production with sites of transfer and locations storage. This volume focuses on siliciclastic systems, but other sedimentary systems can similarly be examined (e.g., carbonate reefs; Ryan et al., 2009; Perry et al., 2015)

Insights from S2S research not only help us to understand changes to the Earth and the associated driving processes but also are informative to citizens and societies (e.g., resource extraction and management) and critical to evaluating ecosystem functions on the planet. Earth processes are often explained and represented by flows and boxed regions that illustrate exchanges of mass or energy from one component or area to another, such as global or more detailed diagrams (e.g., Fig. 1). Although informative, these representations are more conceptual than explicit, offering little insight about the timing and interactions of processes driving the change. In contrast, the S2S community is working to measure the specific rates of surface altering processes, sediment transport, and strata development as well as the resulting landscapes and seascapes (Fig. 2; NSF MARGINS Program Science Plans; 2004; Allen, 2008). Armed with this information, we strive to model the past and the future. In other words, the S2S approach aims to quantify changes in the continuum of the Earth's surface and relate them to measurable fluxes and accumulations (i.e., strata construction) from specific events or conditions.

\section{Brief History of S2S}

Source-to-sink investigation is not really a new concept or approach. Like Hutton, geologists from the beginning have recognized the relationship between catchment soils and seafloor strata, and many have understood that a mass- (or volume) balance approach could be used to understand the Earth system and the interconnections between its parts. Since World War I, research related to strategic, resource (e.g., hydrocarbons), and environmental concerns has 
intensified, and today, the tools and techniques are easier to apply. For example, fluvial systems are key areas for agricultural, environmental and developmental reasons (Fig. 2), and they have received much research attention. Also, geoscientists have maintained a strong focus on understanding continental margins (Fig. 2). This transition zone between land and sea is a critical interface for societies and scientists. These areas, where many humans live and work, are important for resources and serve as key repositories of geological information.

A wonderful early example of S2S research comes from G.K. Gilbert, a legend in the field of geomorphology who worked at the U.S. Geological Survey. His oft-cited study of the impact of hydraulic mining on sedimentation in the Sacramento River and San Francisco Bay region (Gilbert, 1917) provides a thorough analysis of sediment eroded from the catchment and deposited downstream in the 1849-1914 period. This work demonstrates not only the value of an S2S perspective but also the potential hydrological ramifications of sedimentation and the societal relevance of such research (i.e., increased flooding). Hydraulic mining in the late $19^{\text {th }}$ century dramatically altered the landscape in this area, causing profound environmental changes. Gilbert (1917) estimated that $1.8 \times 10^{9} \mathrm{~m}^{3}$ of sediment were eroded from the Sacramento and San Joachim catchments as a result of mining and non-mining processes (e.g., agriculture, roads), and storage of this material occurred in the Sierra (11.1\%), piedmont (21.9\%), valleys $(4.2 \%)$, marshes (12.2 \%), bays (48.3 \%) and ocean (2.1\%). Despite local concern and national attention, this research showed that there was no measurable shoaling near the Bay mouth (i.e., in the vicinity of the Golden Gate Bridge), and thus navigation was not likely to be impacted as some had suggested. However, shoaling of rivers in the piedmont did augment flooding threats within the low-gradient river portion of the source-to-sink system, where evolution continues today (Singer et al., 2013). The work by Gilbert is compelling, illustrating how earth surface dynamics can be greatly affected by human actions.

As demonstrated by Gilbert, estimation of sediment mass added to or removed from various storage zones along its transport pathway is a valuable means to evaluate sedimentary systems, and this is a fundamental component of S2S research. In simple terms, this is the application of mass conservation to geomorphic processes; a sediment budget is literally an assessment of the economy of the Earth's surface. The sediment budget approach has been a fundamental part of coastal research since Bowen and Inman (1966) evaluated littoral cells in southern California. Many similar studies have since transpired, and a variety of concerns must be considered when constructing a meaningful nearshore sediment budget (Komar et al., 1996; Rosati et al., 2005). These coastal studies differ from S2S investigation in that they focus on the functioning of a specific component (i.e., the littoral zone) rather than a whole production and dispersal system. Nevertheless, even in localized studies, a broad S2S perspective is important to maintain. For example, Limber et al. (2008) recommended the use of a "Littoral Cutoff Diameter" because the entire sediment population from a river source does not factor into nearshore sediment dynamics, and thus a littoral sediment budget should be adjusted accordingly.

Efforts to construct system sediment budgets have become more common as techniques to quantify sediment production (e.g., with ${ }^{10} \mathrm{Be}$; Bierman and Nichols, 2004; Nichols et al., 2005) and sediment accumulation (e.g., with ${ }^{210} \mathrm{~Pb}$; Nittrouer et al., 1979; Sommerfield et al., 1999) have improved. Volumetrically linking catchment erosion and deep marine strata over late Quaternary (e.g., Covault et al., 2011) and longer timescales (Carvajal and Steel, 2011) supports 
the utility of a S2S sediment budget approach at large spatial and temporal scales. As studies continue to improve in resolution and expand to other sites, there is potential to compare and contrast systems. Somme (2009) used sediment volume to find general relationships between river sediment load (source) and submarine fans (sinks). Sediment budgets have also been employed to show how shelf width relates to off-shelf transport (Walsh and Nittrouer, 2003), and can explain differences in S2S dispersal systems when coupled with other data (Walsh and Nittrouer, 2009).

A key paper published in the early 1990s was very influential to S2S research. Milliman and Syvitski (1992) documented the great number of small rivers with large sediment yields on active margins, and hypothesized that rapid delivery of sediment to steep-gradient continental margins may be critical to sediment and carbon storage in the sea. These ideas helped motivate a flood of research focused on small, mountains dispersal systems. The STRATAFORM program, which began in the mid-1990s, addressed this hypothesis and explored strata development over a range of times scales. Research focused on two margins, the active Eel River margin (California) and the passive New Jersey margin. While terrestrial research was not a major part of STRATAFORM, study of the Eel margin emphasized the modern processes and specifically examined river-ocean sediment transfer over event and longer timescales. New Jersey margin research focused on the longer (primarily Quaternary) geological history of strata formation. A wealth of research was published (see Nittrouer et al., 1999; Wheatcroft, 2000; Nittrouer et al., 2007 and references). Following this program a similar international effort, EUROSTRATAFORM, investigated the Po and Rhone rivers of the Mediterranean and their associated dispersal systems (Weaver et al., 2006; Milligan and Cattaneo, 2007; Durrieu de Madron et al., 2008 and references therein).

An increasing number of research projects have employed an S2S philosophy over the last decade, and many look to the future with innovative methods and models. For example, the U.S. Geological Survey and others recently conducted a more detailed analysis of the San Francisco Bay sedimentary system (see Barnard et al., 2013, and references therein). Their analysis built on the study of Gilbert and others and provided a nice demonstration of the S2S approach. The dominant role that the coastal system plays in sediment storage for this activemargin system should remind us of the great diversity of sedimentary systems around the globe. This work illustrated how humans have influenced many aspects of the coast. Moreover, climate change is predicted to have notable impacts on various processes and conditions that will affect S2S dispersal systems (Cloern et al., 2010).

Recognizing the importance of and need to expand our geological understanding of the transition zone between terrestrial and marine systems, The U.S. National Science Foundation initiated planning for the MARGINS program in the 1990s, and "Source to Sink", often referred to as "S2S", was developed as one of four major initiatives (NSF MARGINS Program, 2004; http://www.nsf-margins.org/). A series of meetings in September-October 1999 (Lake Quinault; Nittrouer and Driscoll, 2000), and September 2000 (Lake Tahoe; Nittrouer and Driscoll, 2001) were instrumental in obtaining community input to create the implementation plan for the 10year program and selecting the focus areas for the research. The Fly River (Papua New Guinea, Gulf of Papua) and Waipaoa River (New Zealand, east side of the North Island) dispersal systems were established as primary study sites. For both sites, previous and ongoing work 
outside of the MARGINS program provided a valuable foundation of knowledge about systems upon which to build. According to the original science plan, the S2S Initiative "will provide a comprehensive study of linked, terrestrial and marine sediment dispersal systems over the range of time scales for which sedimentary processes operate. Observational, laboratory and theoretical studies will be integrated to allow the modeling of entire, linked sedimentary systems as opposed to only their components. Questions center around the role of changing tectonics, climate and sea level as forcing functions in the production, transport and storage of sediments and solutes, the processes initiating erosion and sediment transfer, and their interactions; and the interplay of sedimentary processes and forcing functions in creating the stratigraphic record.” As impetus for the research, the science plan highlighted how the S2S system contains most of the Earth's water and energy resources and that most humans live along S2S pathways. Central motivations of this NSF Margins research were to comprehend how the basic hypsometric components of the Earth (Fig. 3 top) are linked as well as how sedimentary signals are transferred between these regions (Fig. 3 bottom). Ultimately, the latter determines to what degree the stratigraphic record can be used to reconstruct the past.

The compact size yet strong sediment signal ( $15 \mathrm{Mt} / \mathrm{y})$ produced by the tectonically active Waipaoa River system were among the reasons for its selection for the MARGINS program. Research associated with this study area is thoroughly reviewed by Kuehl et al. (this volume), in addition to a couple of focused special issues (Carter et al., 2010; Corbett et al., 2014). Readers are directed to Kuehl et al., (this volume) to learn more about specific studies. With its extensive river network, the Fly River study site (Papua New Guinea) provides a nice contrast. The Fly was selected because of its large, mining-influenced sediment load ( 115 Mt/y), its active channels and floodplains (Aalto and Dietrich, 2005), and the monsoonal and ENSO conditions affecting its receiving basin, the Gulf of Papua (Walsh et al., 2003). A large special issue of the Journal of Geophysical Research (2008, Volume 113, Issue F1) includes many papers resulting from this study. Some interesting insights includes the importance of river-floodplain exchange (Aalto et al., 2008), spatial variability in fluid-mud formation (Ogston et al., 2008), carbon loading (Goni et al., 2008) and clinothem and deep-sea sedimentation (Crockett et al., 2008; Francis et al., 2008; Slingerland et al., 2008).

The Chapman Conference held in Oxnard, CA, in January 2011 showcased the global extent of S2S research (Kuehl and Nittrouer, 2011). Moreover, the involvement of many scientists from the oil and gas industry highlighted how the S2S philosophy was being employed for not only modern studies but also deep-time investigations. To bring together the community and build momentum for this volume, a special session was held at Fall AGU Meeting in 2013. Over 50 abstracts were submitted, giving testimony to the widespread and ongoing S2S research activity.

One important result of the S2S collaboration was the spawning of the Community Surface Dynamics Modeling System (CSDMS) program (Syvitski et al., 2004). Modeling of surface processes over a range of temporal and spatial scales has long been of part of S2S endeavors. Some examples of model usage include: flood- and storm-driven sediment dispersal in the sea (Bever et al., 2014; Moriarity et al., 2014), river discharge and sediment flux over the late Holocene (Kettner et al., 2007) and signal propagation (Castelltort and Van den Driessche, 2003; Jerolmack and Paola, 2010). The CSDMS program facilitates modeling of S2S systems by 
providing access to models and computational infrastructure to link models of different parts of the system (see Section 4 Future of S2S Research).

\section{Construction of this volume}

Over the last decade, many studies have carefully examined sedimentary systems across a range of temporal scales from the perspective of sediment production in source, storage in sinks, and linkage between them. This research has great societal relevance in terms of understanding material cycling, geologic history and the availability of natural resources (e.g., hydrocarbons). This volume brings together diverse yet related work to address the functioning of and strata development in different sediment dispersal systems. The overall objective of this volume is to showcase and synthesize S2S science and to explore the complex and varied behavior of individual siliciclastic sedimentary systems as well as cross-cutting concepts such as signal propagation.

At the S2S Chapman Conference in 2011, the attendees strongly agreed that this volume should try to avoid reviewing research in a spatially compartmentalized fashion. As a result, this volume includes two types of papers; four that address cross-cutting topics while the remaining eight are system-focused examples. The time scale of focus for these chapters is varied, as it was not reasonable to expect all topics/systems to cover all of geologic time. The cross-cutting papers address signal generation and propagation (Romans et al., this volume), carbon processing (Leithold et al., this volume), glacier-influenced S2S systems (Jaeger and Koppes, this volume) and the application of S2S to deep time (Bhattacharya et al., this volume). Dispersal system examples cover a wide range of spatial (Fig. 4) and temporal (modern to ancient) scales, and as a result the sedimentary signals (e.g., flood, climate change) that can be resolved are different, and will be impacted to varying degrees by noise, lags and shredding (Fig. 3; see Romans et al., this volume). Specifically, the system examples include (Fig. 4): Gaoping (Taiwan; J. Liu et al., this volume), Mississippi (USA; Bentley et al., this volume), northwestern Gulf of Mexico (e.g., Brazos River, Texas, USA; Anderson et al., this volume), Po (Italy; Amorosi et al., this volume), South China Sea (Z. Liu et al., this volume), Tagus (Portugal; Vis et al., this volume), Wabush Lake (Canada; Turmel et al., this volume), and Waipaoa (New Zealand, Kuehl et al., this volume).

\section{Future of S2S Research}

All of the papers of this volume provide some insights into the path forward for S2S research, and the many thoughts and recommendations cannot be reviewed here. Nevertheless, having invested many hours pondering the state of the science, we are compelled to convey four critical areas where the S2S community needs to advance in the future:

1) Linking present and the past - there continues to be too much community disconnect among “modern” (process), Quaternary and deep-time researchers.

2) Modeling is critical - not only to better understand complex physical processes today but also to improve the linkage between present and past (\#1). Models that encompass multiple links in source-to-sink systems and over timescales of millennia or longer would be especially valuable, and are now feasible given advances in computational power. 
3) Making more measurements and observations. We cannot stop exploring and examining the world. The more we look; the more we learn, and new technologies and techniques will open our eyes wider and deepen our perspective, knowledge, and ability to correctly parameterize a new generation of models (\#2).

4) Highlighting the societal relevance of S2S research. The coastal deltaic deposits on which many populous cities lie are a key intermediate sediment storage zones in the S2S system. Understanding the impacts of changes in the terrestrial and marine portions of these highly sensitive systems will be critical to any attempts to assess vulnerability and options for ameliorating the impacts of climate change and sea-level rise.

\section{References}

Aalto, R., J. W. Lauer, and W. E. Dietrich (2008), Spatial and temporal dynamics of sediment accumulation and exchange along Strickland River floodplains (Papua New Guinea) over decadal-to-centennial timescales, J. Geophys. Res., 113, F01S04, doi:10.1029/2006JF000627.

Aalto, R., and Dietrich, W., 2005, Sediment accumulation determined with Pb-210 geochronology for Strickland River flood plains, Papua New Guinea, in Walling, D.E., and Horowitz, A.J., eds., Sediment Budgets I: Wallingford, UK, IAHS Press, v. 291, p. 303-309.

Allen, P. (2008). From landscapes into geological history Nature, 451 (7176), 274-276 DOI:10.1038/nature06586.

Amorosi, A., Maselli, V., \& Trincardi, F., 2015. Onshore to offshore anatomy of a late Quaternary source-to-sink system (Po Plain-Adriatic Sea, Italy). Earth Sci. Rev. (in this volume).

Anderson, J.B., Wallace, D.J., Simms, A.R., Rodriguez, A.B., Weight, R.W.R., \& Taha, Z.P., 2015. Recycling sediments between source and sink during a eustatic cycle: Systems of late Quaternary northwestern Gulf of Mexico Basin. Earth Sci. Rev. (in this volume).

Barnard, P.L., Schoellhamer, D.H., Jaffe, B.E., McKee, L.J., 2013. Sediment transport in the San Francisco Bay Coastal System: An overview. Mar. Geol. 345, 3-17.

Bentley, S.J., Blum, M.D., Maloney, J., Pond, L.G., \& Paulsell, R.L., 2015. The Mississippi River source-to-sink system: Perspectives on tectonic, climatic, and anthropogenic influences, Miocene to Anthropocene. Earth Sci. Rev. (in this volume).

Bever, A.J., Harris, C.K., 2014. Storm and fair-weather driven sediment-transport within Poverty Bay, New Zealand, evaluated using coupled numerical models. Cont. Shelf Res, 86, 3451.

Bhattacharya, J.P., Copeland, P., Lawton, T.F., \& Holbrook, J., 2015. Estimation of source area, river paleo-discharge, paleoslope, and sediment budgets of linked deep-time depositional systems and implications for hydrocarbon potential. Earth Sci. Rev. (in this volume). 
Bierman, P., and Nichols, K., 2004, Rock to sediment - Slope to sea with 10-Be - Rates of landscape change: Annual review of Earth and Planetary Sciences, v. 32, p. 215-255.

Bowen, A.J. and Inman. D.L., 1966. Budget of Littoral Sand in the Vicinity of Point Arguello, California. U.S. Army Coastal Engineering Research Center, Technical Memorandum No. 19, $56 \mathrm{p}$.

Carter, L., Orpin, A.R., Kuehl, S.A., 2010. From mountain source to ocean sink - the passage of sediment across an active margin, Waipaoa Sedimentary System, New Zealand. Mar. Geol. 270, $1-10$.

Carvajal, C. and Steel, R. 2011. Source-to-Sink Sediment Volumes within a TectonoStratigraphic Model for a Laramide Shelf-to-Deep-Water Basin: Methods and Results, in Tectonics of Sedimentary Basins: Recent Advances (eds C. Busby and A. Azor), John Wiley \& Sons, Ltd, Chichester, UK. doi: 10.1002/9781444347166.ch7

Castelltort, S. and Van den Driessche, J. (2003) How plausibleare high-frequency sediment supply-driven cycles in the stra-tigraphic record? Sediment. Geol., 157,3-13.

Cloern, J.E., Knowles, N., Brown, L.R., Cayan, D., Dettinger, M.D., Morgan, T.L., Schoellhamer, D.H., Stacey, M.T., van der Wegen, M., Wagner, R.W., Jassby, A.D., 2011. Projected evolution of California's San Francisco Bay-Delta-River system in a century of climate change. PLoS One 6 (9) (13 pp.).

Corbett, D.R., Walsh, J.P., Harris, C.K., Ogston, A.S., Orpin, A.R., 2014. Formation and preservation of sedimentary strata from coastal events: Insights from measurements and modeling. Cont. Shelf Res. 86, 1-5.

Covault, J.A., Romans, B.W., Graham, S.A., Fildani, A., and Hilley, G.E., 2011, Terrestrial source to deep-sea sink sediment budgets at high and low sea levels: Insights from tectonically active southern California. Geology. 39: 619-622.

Crockett J. S., Nittrouer C. A., Ogston A. S., Naar D. F. and Donahue B. T. (2008) Morphology and filling of incised submarine valleys on the continental shelf near the mouth of the Fly River, Gulf of Papua. J. Geophys. Res. Earth Surf. 113(F1).

Durrieu de Madron, X., Wiberg, P.L., Puig, P., 2008. Sediment dynamics in the Gulf of Lions: The impact of extreme events. Cont. Shelf Res. 28, 1867-1876.

Francis, J. M., J. J. Daniell, A. W. Droxler, G. R. Dickens, S. J. Bentley, L. C. Peterson, B. N. Opdyke, and L. Beaufort (2008), Deep water geomorphology of the mixed siliciclastic-carbonate system, Gulf of Papua, J. Geophys. Res., 113, F01S16, doi:10.1029/2007JF000851.

Gilbert, G.K., 1917. Hydraulic-mining debris in the Sierra Nevada. U.S. Geological Survey Professional Paper 105. 154 pgs. 
Goni, M. A., N. Monacci, R. Gisewhite, J. Crockett, C. Nittrouer, A. Ogston, S. R. Alin, and R. Aalto (2008), Terrigenous organic matter in sediments from the Fly River delta-clinoform system (Papua New Guinea), J. Geophys. Res., 113, F01S10, doi:10.1029/2006JF000653.

Hutton, J., 1785 (published 1788). Theory of the Earth. Trans. R. Soc. Edinburgh. 1: 209-304.

Jaeger, J.M., \& Koppes, M.N., 2015. The role of the cryosphere in source-to-sink systems. Earth Sci. Rev. (in this volume).

Jerolmack, D. J., and C. Paola (2010), Shredding of environmental signals by sediment transport, Geophys. Res. Lett., 37, L19401, doi:10.1029/2010GL044638.

Komar, P.D. 1996. The budget of littoral sediments - concepts and applications. Shore and Beach, 64(3), 18-26.

Kuehl, S.A., Alexander, C.R., Blair, N.E., Harris, C.K., Marsaglia, K.M., Ogston, A.S., Orpin, A.R., Roering, J.J., Bever, A.J., Bilderback, E.L., Carter, L., Cerovski-Darriau, C., Childress, L.B., Corbett, D.R., Hale, R.P., Leithold, E.L., Litchfield, N., Moriarty, J.M., Page, M.J., Pierce, L.E.R., Upton, P. and Walsh, J.P. 2015. A Source to Sink perspective of the Waipaoa River margin. Earth-Science Reviews. DOI: 10.1016/j.earscirev.2015.10.001.

Kettner, A. J., B. Gomez, and J. P. M. Syvitski (2007), Modeling suspended sediment discharge from the Waipaoa River system, New Zealand: The last 3000 years, Water Resour. Res., 43, W07411, doi:10.1029/2006WR005570.

Kuehl, S.A. and C.A. Nittrouer, 2011. Exploring the transfer of Earth surface materials from source to sink, Eos, 92188.

Kuehl., S.A., Alexander, C.R., Blair, N.E., Harris, C.K., Marsaglia, K.M., Ogston, A.S., Orpin, A.R., Roering, J.J., Bever, A.J., Bilderback, E.L., Carter, L., Cerovski-Darriau, C., Childress, L.B., Corbett, D.R., Hale, R.P., Leithold, E.L., Litchfield, N., Moriarty, J.M., Page, M.J., Pierce, L.E.R, Upton, P., \& Walsh, J.P., 2015. A source-to-sink perspective of the Waipaoa River margin. Earth Sci. Rev. (in this volume).

Leithold, E.L., Blair, N.E., \& Wegmann, K.W., 2015. Source to sink sedimentary systems and the global C-cycle: A river runs through it. Earth Sci. Rev. (in this volume).

Limber, P.W., Patsch, K.B., and Griggs, G.B., 2008. Coastal sediment budgets and the littoral cut-off diameter: a sediment grain-size threshold for quantifying active sediment inputs. Journal of Coastal Research, 24, 122-133.

Liu, J.T., Hsu, R.T., Hung, J.-J., Chang, Y.P., Wang, Y.-H., Rendle- Bühring, R.U., Lee, C.-L., Huh, C.-A., \& Yang, R.J., 2015. From the highest to the deepest: The Gaoping River-Gaoping Submarine Canyon dispersal system. Earth Sci. Rev. (in this volume). 
Liu, Z., Zhao, Y., Colin, C., Stattegger, K., Wiesner, M.G., Huh, C.-A., Zhang, Y., Li, X., Sompongchaiyakul, P., You, C.-F., Huang, C.-Y., Liu, J.T., Siringan, F.P., Le, K.P., Sathiamurthy, E., Hantoro, W.S., Liu, J., Tuo, S., Zhoa, S., Zhou, S., He, Z., Wang, Y., Bunsomboonsakul., S., \& Li, Y. 2015. Source-to-sink transport processes of fluvial sediments in the South China Sea. Earth Sci. Rev. (in this volume).

Milligan, T.G., Cattaneo, A., 2007. Sediment dynamics in the western Adriatic Sea: From transport to stratigraphy. Cont. Shelf Res. 27, 287-295.

Milliman, J.D., Syvitski, J.P.M., 1992. Geomorphic/tectonic control of sediment discharge to the ocean: the importance of small mountainous rivers. Journal of Geology 100: 525-544.

Moriarty, J.M., Harris, C.K., Hadfield, M.G., 2014. A hydrodynamic and sediment transport model for the Waipaoa Shelf, New Zealand: Sensitivity of fluxes to spatially-varying erodibility and model nesting. J. Mar. Sci. Eng., 2(2), 336-369.

Nichols, K.K., Bierman, P.R., Caffee, M., Finkel, R., and Larsen, J., 2005, Cosmogenically enabled sediment budgeting. Geology, 33: 133-136.

Nittrouer, C.A., 1999. STRATAFORM: overview of its design and synthesis of its results. Mar. Geol. 154, 3-12.

Nittrouer and Driscoll, 2000. Source to Sink Studies. JOI/USSAC Newsletter: 16-18 pgs. http://usssp-iodp.org/wp-content/uploads/Workshop_SourceToSink_Report.pdf

Nittrouer and Driscoll, 2001. MARGINS Source-to-Sink Lake Tahoe Workshop Report: An Implementation Plan. MARGINS Newsletter No. 6, pgs. 15-18.

http://usssp-iodp.org/wp-content/uploads/Workshop_SourceToSinkImplementation_Report.pdf

Nittrouer, C.A., Sternberg, R .W., Carpenter, R. and Bennett, J.T., 1979. The use of Pb-210 geochronology as a sedimentological tool: application to the Washington continental shelf. Mar. Geol., 31: 297-316.

Nittrouer, C.A., Austin, J.A., Field, M.E., Kravitz, J.H., Syvitski, J.M.P., Wiberg, P.I., 2007. Writing a Rosetta Stone: Insights into Continental-Margin Sedimentary Processes and Strata, Special Publication 37 of the International Association of Sedimentologists. Blackwell Publishing Ltd., Oxford 549 pp.

NSF MARGINS Program Science Plans. 2004. 170 pp. http://www.nsfmargins.org/Publications/SciencePlans/MARGINS_SciencePlans2004.pdf.

Ogston, A.S., Sternberg, R.W., Nittrouer, C.A., Martin, D.P., Gõni, M.A., Crockett, J.S., 2008. Sediment delivery from the Fly River tidally dominated delta to the nearshore marine environment and the impact of El Nino. Journal of Geophysical Research 113, F01S11, doi:10.1029/2006JF000669. 
Perry, C.T., Kench, P.S., O'Leary, M.J., Morgan, K.M., \& Januchowski-Hartley, F., 2015. Linking reef ecology to island building; parrotfish identified as major producers of islandbuilding sediment in the Maldives. Geology, 43(6): 503-506.

Romans, B.W., Castelltort, S., Covault, J.A., Fildani, A., \& Walsh, J.P., 2015. Environmental signal propagation in sedimentary systems across timescales. Earth Sci. Rev. (in this volume)

Rosati, J.D. 2005. Concepts in Sediment Budgets. Journal of Coastal Research: Volume 21, Issue 2: pp. $307-322$.

Ryan, K.E., Walsh, J.P., Corbett, D.R., Dail., M.B., Nittrouer, J. \& Winter, A., 2009. Modern sedimentation in a mixed siliciclastic-carbonate coral reef environment, La Parguera, Puerto Rico. Caribbean Journal of Science, 45 (2-3), 151-167

Slingerland, R., N. W. Driscoll, J. D. Milliman, S. R. Miller, and E. A. Johnstone (2008), Anatomy and growth of a Holocene clinothem in the Gulf of Papua, J. Geophys. Res., 113, F01S13, doi:10.1029/2006JF000628.

Singer, M.B., Aalto. R., James, L.A., Kilham, N.E., Higson, J.L., Ghoshal, S., 2013, Enduring legacy of a toxic fan via episodic redistribution of California gold mining debris, Proceedings of the National Academy of Sciences, 110 (46), 18436-18441.

Somme, T.O., Helland-Hansen, W., Martinsen, O.J., and Thurmond, J.B., 2009, Relationships between morphological and sedimentological parameters in source-to-sink systems: A basis for predicting semi-quantitative characteristics in subsurface systems: Basin Research, v. 21, p. 361387.

Sommerfield, C.K., Nittrouer, C.A., 1999. Modern accumulation rates and a sediment budget for the Eel shelf: a flood-dominated depositional environment. Mar. Geol. 154 (1-4), 227-241.

Syvitski, J.P.M.; Paola, R.; Slingerland, R.; Furbish, D.; Wiberg, P.; Tucker, G. (2004). Building a community surface Dynamics modeling system rationale and strategy. A Report to the National Science Foundation. State College, Pennsylvania: Penn State University. p. 41.

Turmel, D., Parker, G. \& Locat, J., 2015. Evolution of an anthropic source-to-sink system: Wabush Lake. Earth Sci. Rev. (in this volume).

Vis, G.-J., Kasse, C., Kroon, D., Vandenberghe, J., Jung, S., Lebreiro, S.M., \& Rodrigues, T., Time-integrated 3D approach of late Quaternary sediment-depocentre migration in the Tagus depositional system: From river valley to abyssal plain. Earth Sci. Rev. (in this volume).

Walsh, J.P. and C.A. Nittrouer. 2003. Contrasting styles of off-shelf sediment accumulation in New Guinea. Marine Geology, 196: 105-125. 
Walsh, J.P., Nittrouer, C.A., Palinkas, C., Ogston, A.S., Sternberg, R.W., and G.J. Brunskill. 2004. Clinoform mechanics in the Gulf of Papua, New Guinea. Continental Shelf Research, 24: 2487-2510.

Walsh, J.P. and C.A. Nittrouer. 2009. Towards an Understanding of Fine-grained RiverSediment Dispersal on Continental Margins. Marine Geology, 263: 34-45.

Weaver, P.P.E., Canals, M., Trincardi, F., 2006. EUROSTRATAFORM Special Issue of Marine Geology. Mar. Geol. 234, 1-2.

Wheatcroft, R.A., 2000. Oceanic flood sedimentation: a new perspective. Cont. Shelf Res. 20, 2059-2066. 


\section{FIGURES}

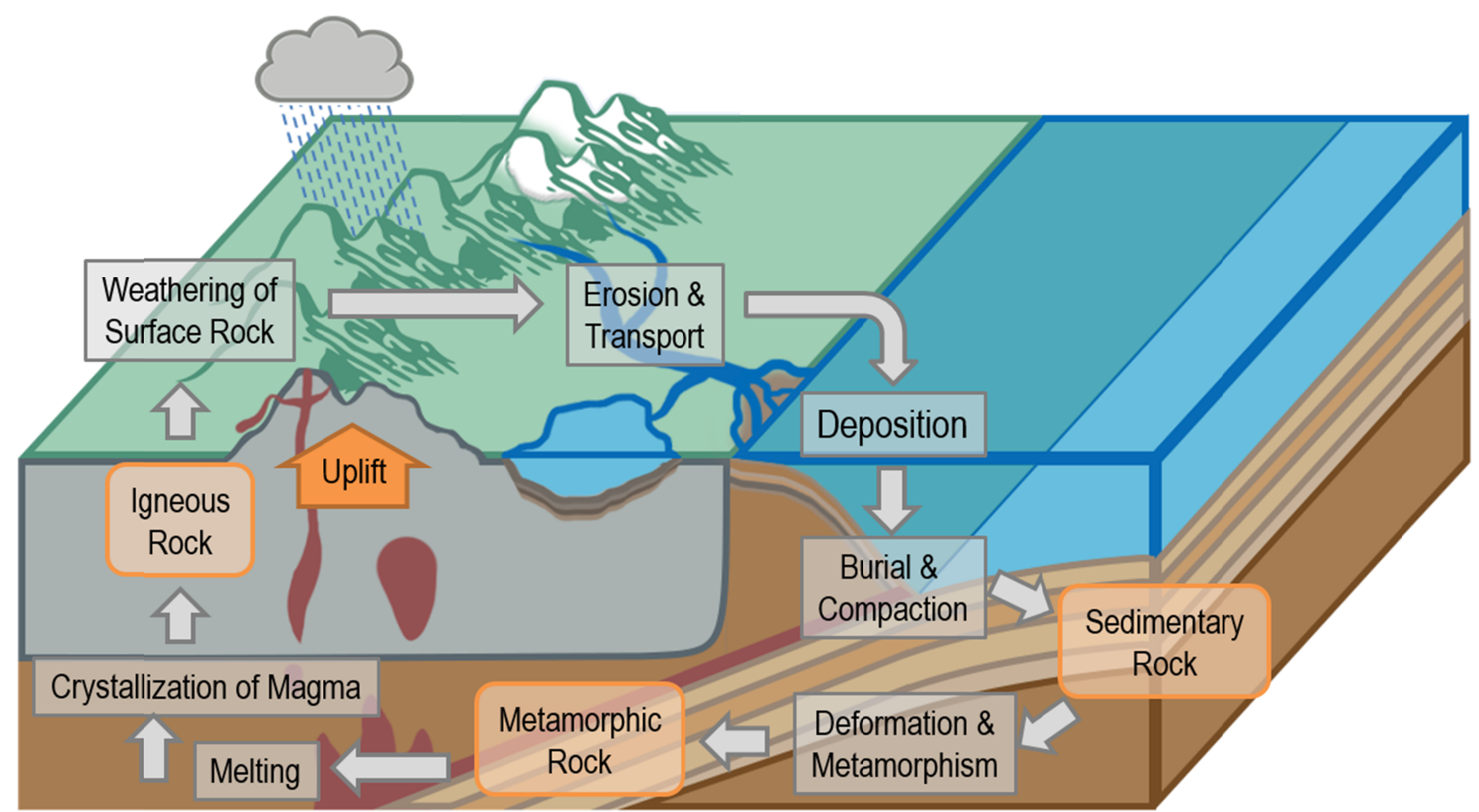

Figure 1: A conceptual diagram of the evolving Earth, showing mass flows over geologic time, often referred to as the "Rock Cycle". Note, sediment erosion, transport and deposition are fundamental and variable components of siliciclastic S2S systems and have been quantified and modeled in many areas. 


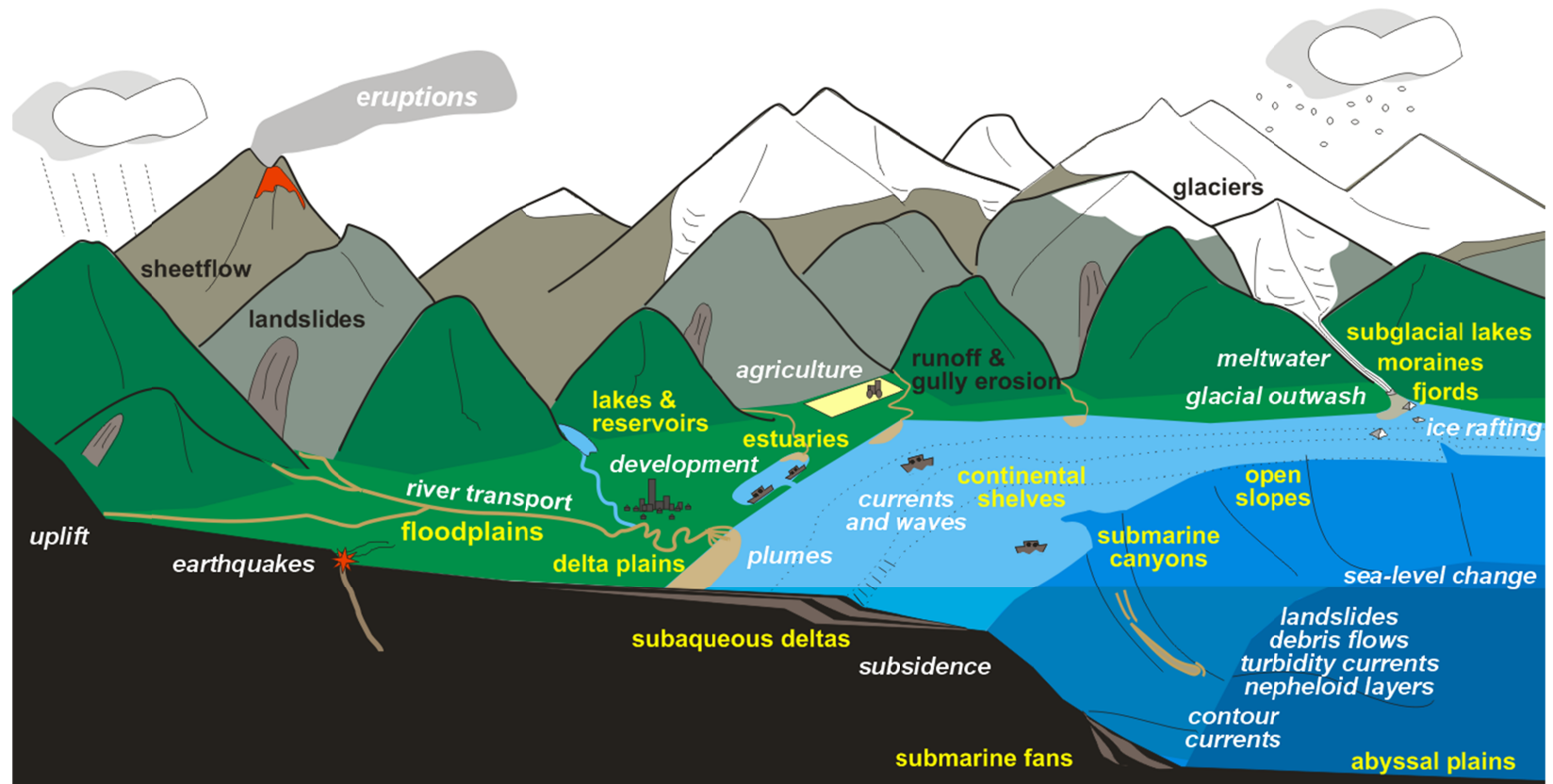

Figure 2: Sources (black), sinks (yellow) and processes (white) moving sediment (modified from NSF MARGINS Program Science Plans, 2004). Note, carbonate systems are excluded to simplify. 

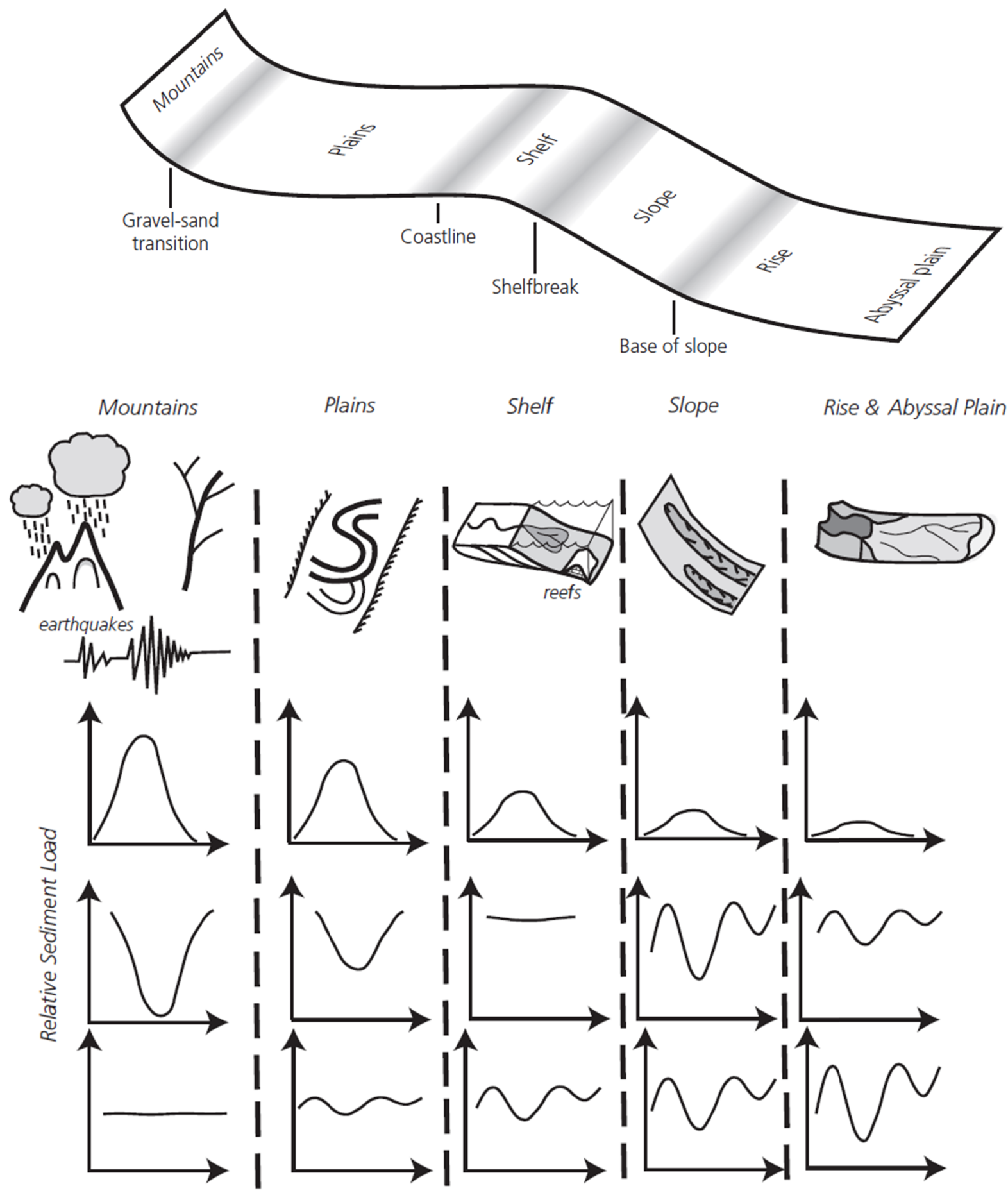

Figure 3. Potential components of a S2S systems (top) and conceptual diagram on possible signal modification (bottom) (NSF MARGINS Program Science Plans, 2004). Note how sedimentary signals can vary within a system depending on production processes (i.e., look at the leftmost column in the diagram). Also, these signals can change as they propagate down a system (moving left to right) as a result of storage (e.g., top row of signals) or other signalaltering processes (e.g., marine conditions, bottom row of signals). 


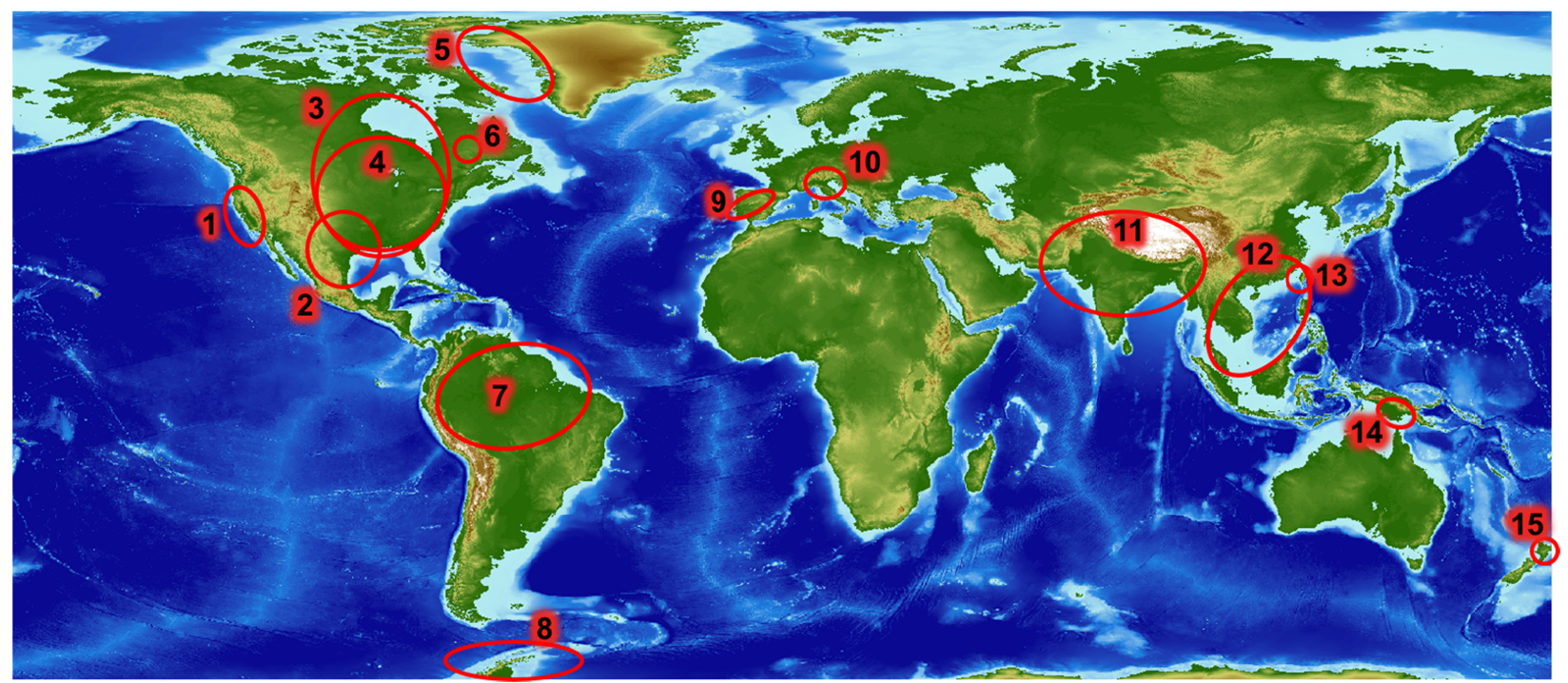

Figure 4: Map showing many of the S2S systems discussed in this special issue. Numbers indicate: 1) California rivers (Leithold et al., this volume; Romans et al., this volume), 2) rivers draining into northwestern Gulf of Mexico (e.g., Brazos; Anderson et al., this volume), 3) Cretaceous rivers of central North America (Bhattacharya et al., this volume), 4) Mississippi River (Bentley et al., this volume; Leithold et al., this volume), 5) Baffin Bay (Jaeger and Koppes, this volume), 6) Wabush Lake in Canada (Turmel et al., this volume), 7) Amazon (Leithold et al., this volume), 8) glaciers of the Antarctic Peninsula, 9) Tagus River crossing Portugal (Vis et al., this volume), 10) Po River of Italy (Amorosi et al., this volume), 11) Indus and Ganges-Brahmaputra rivers (Romans et al., this volume), 12) South China Sea (Z. Liu et al., this volume), 13) Gaoping River of Taiwan (J. Liu et al., this volume), 14) Fly River of New Guinea (Leithold et al, this volume) and 15) Waipaoa River of New Zealand (Kuehl et al., this volume). 